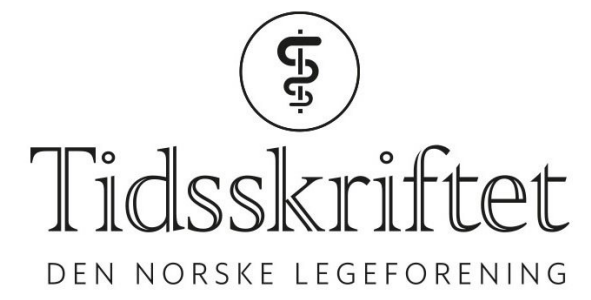

\title{
Kan genetiske risikoscorer nyansere LDL-kolesterolets rolle?
}

DEBATT

\section{KARSTEN $\varnothing$ VRETVEIT}

E-post: karsten.ovretveit@ntnu.no

Karsten $\emptyset$ vretveit er stipendiat ved Fakultet for medisin og helsevitenskap ved NTNU. Forfatteren har fylt ut ICMJE-skjemaet og oppgir ingen interessekonflikter.

Modifisering av risikofaktorer for hjerte- og karsykdom kan ha større effekt tidlig i livet. Kan og bør man kartlegge predisposisjon tidligere og med andre metoder enn i dag?

LDL-kolesterol (low density lipoprotein) er en av de viktigste kausale risikofaktorene for aterosklerotisk hjerte- og karsykdom (1). Den aterosklerotiske prosessen starter tidlig i livet og tiltar med alderen. Eksponeringstiden ( $\mathrm{mmol} / \mathrm{L} \times$ år) er avgjørende for utfallet, der livslang eksponering for lavere nivåer av aterogene faktorer er forbundet med redusert risiko for kardiovaskulær sykdom (2). I Norge brukes risikomodellen NORRISK 2 for å estimere tiårsrisiko for hjerteinfarkt og hjerneslag for individer over 45 år, og den har blant annet vist god evne til å identifisere høyrisikoindivider (3). I modellen inngår variabler som alder, systolisk blodtrykk, totalkolesterol og familiehistorikk. Spesifikk genetisk informasjon utover familiehistorikk inkluderes ikke, til tross for at slike data tilsynelatende har lovende klinisk verdi (4). Nylig ble det imidlertid vist at det å kombinere en genetisk risikoscore med tradisjonelle risikofaktorer hadde liten effekt på risikoestimater for kardiovaskulær sykdom (5, 6). Det er derfor nærliggende å tro at genetiske data ikke har noen plass i primærforebygging av hjerte- og karsykdom - men er det riktig slutning?

\section{Tiden leger ikke alle sår}

Når man sammenligner genetiske risikoscorer med etablerte risikomodeller, er det grunnleggende at man i tillegg til hva de forteller oss, tar i betraktning når de kan fortelle oss det. Genetisk risiko kan kalkuleres fra fødselen, mens tradisjonelle risikofaktorer forteller lite om kardiovaskulær sykdomsrisiko før patologiske fenotyper som hypertensjon og høyt kolesterolnivå har kommet til uttrykk. I tillegg vil en mann uten åpenbare risikofaktorer som er gammel nok for NORRISK 2, gjerne allerede ha subklinisk aterosklerose og følgelig økt sykdomsrisiko som ikke fanges opp (7).

Det gir liten mening å sammenligne effekten av en tradisjonell prediksjonsmodell med en som også inkluderer genetisk data, nettopp fordi en av hovedstyrkene til genetisk risiko er at den er medfødt og kan si noe om risikoen for å utvikle en fenotype før den har manifestert seg. Med tanke på hvor viktig kumulativ eksponering for risikofaktorer som LDL-kolesterol er for endelig sykdomsrisiko, virker det åpenbart at genetiske data kan gi verdifull tilleggsinformasjon til tradisjonelle undersøkelser, særlig ut fra et preventivt 
perspektiv.

\section{Forebygging bør være sentralt}

Nylig kunne funn fra CARDIA-studien (Coronary Artery Risk Development in Young Adults) vise hvordan total eksponeringstid modifiserer kardiovaskulær risiko assosiert med LDLkolesterol (8). Det man også så, var at når perioden med forhøyet LDL-kolesterolnivå inntraff, var en viktig uavhengig risikofaktor; jo tidligere i livet eksponeringen fant sted, desto større var den senere risikoen. Med andre ord hadde personene med stigende LDLkolesterolnivå lavere risiko enn de med synkende nivå ved samme totale eksponeringstid.

Det virker åpenbart at genetiske data kan gi verdifull tilleggsinformasjon til tradisjonelle undersøkelser

Gener kan tidlig indikere sykdomsrisiko, noe som åpner for enkel, effektiv og ikkemedikamentell forebygging av vanlige livsstilssykdommer samt muligheten til å dra nytte av effekten av bedre intervensjonstiming. Ettersom redusert eksponeringstid for LDLkolesterol kan ha betydelig preventiv effekt, kan man argumentere for at testing av assosierte genvarianter kan bidra til tiltak tidlig i livet som sikrer god kardiovaskulær helse senere i livet. En genetisk risikoscore vil, i motsetning til score beregnet med tradisjonelle risikomodeller, kunne identifisere høyrisikoindivider før den økte risikoen reflekteres i blodverdiene.

Det finnes mange grunner til at man ikke bør screene mennesker som fremstår som friske, og dette gjelder også bruk av genetiske tester for å grave i risikofaktorer som sannsynligvis aldri vil gjøre seg gjeldende. Når det kommer til modifiserbare og utbredte lidelser som hjerte- og karsykdom, er det imidlertid verdt å utforske alternativer som kan bidra til redusert forekomst. Høy grad av både fenotypisk plastisitet og klinisk signifikans er naturligvis helt avgjørende for om man kan forsvare det å formidle genetisk risiko til pasienter - og det er tilfellet for LDL-kolesterol.

\section{LITTERATUR:}

1. Borén J, Chapman MJ, Krauss RM et al. Low-density lipoproteins cause atherosclerotic cardiovascular disease: pathophysiological, genetic, and therapeutic insights: a consensus statement from the European Atherosclerosis Society Consensus Panel. Eur Heart J 2020; 41: 2313-30. [PubMed][CrossRef]

2. Ference BA, Bhatt DL, Catapano AL et al. Association of genetic variants related to combined exposure to lower low-density lipoproteins and lower systolic blood pressure with lifetime risk of cardiovascular disease. JAMA 2019; 322:1381-91. [PubMed][CrossRef]

3. Mirza Y, Prestgaard EE, Selmer R et al. Tiårsprediksjon av hjerte- og karsykdom hos friske norske menn basert på NORRISK-2. Tidsskr Nor Legeforen 2020; 140. doi:10.4045/tidsskr.20.0089.

[PubMed][CrossRef]

4. Khera AV, Chaffin M, Aragam KG et al. Genome-wide polygenic scores for common diseases identify individuals with risk equivalent to monogenic mutations. Nat Genet 2018; 50: 1219-24. [PubMed][CrossRef]

5. Elliott J, Bodinier B, Bond TA et al. Predictive accuracy of a polygenic risk score-enhanced prediction model vs a clinical risk score for coronary artery disease. JAMA 2020; 323: 636-45. [PubMed][CrossRef]

6. Mosley JD, Gupta DK, Tan J et al. Predictive accuracy of a polygenic risk score compared with a clinical risk score for incident coronary heart disease. JAMA 2020;323: 627-35. [PubMed][CrossRef]

7. Fernández-Friera L, Peñalvo JL, Fernández-Ortiz A et al. Prevalence, vascular distribution, and multiterritorial extent of subclinical atherosclerosis in a middle-aged cohort. Circulation 2015; 131: 2104-13. [PubMed][CrossRef]

8. Domanski MJ, Tian X, Wu CO et al. Time course of LDL cholesterol exposure and cardiovascular disease event risk. J Am Coll Cardiol 2020; 76:1507-16. [PubMed][CrossRef] 
Publisert: 14. desember 2020. Tidsskr Nor Legeforen. DOI: 10.4045/tidsskr.20.0845

Mottatt 20.10.2020, første revisjon innsendt 6.11.2020, godkjent 16.11.2020.

(C) Tidsskrift for Den norske legeforening 2020. Lastet ned fra tidsskriftet.no 